\title{
Joundell of thnnology
}

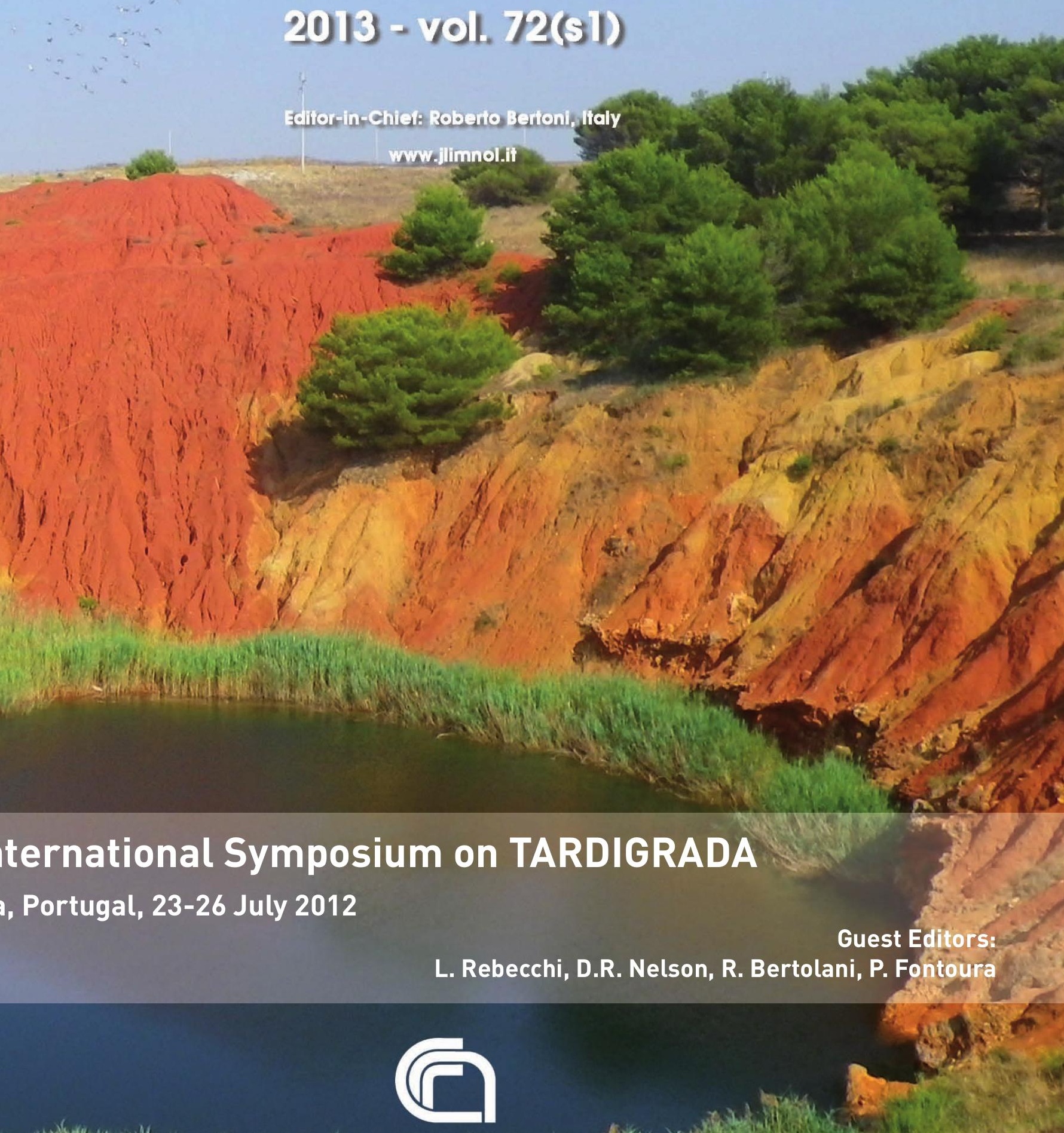

\section{$12^{\text {th }}$ International Symposium on TARDIGRADA}

V.N. Gaia, Portugal, 23-26 July 2012

Guest Editors:

L. Rebecchi, D.R. Nelson, R. Bertolani, P. Fońtoura

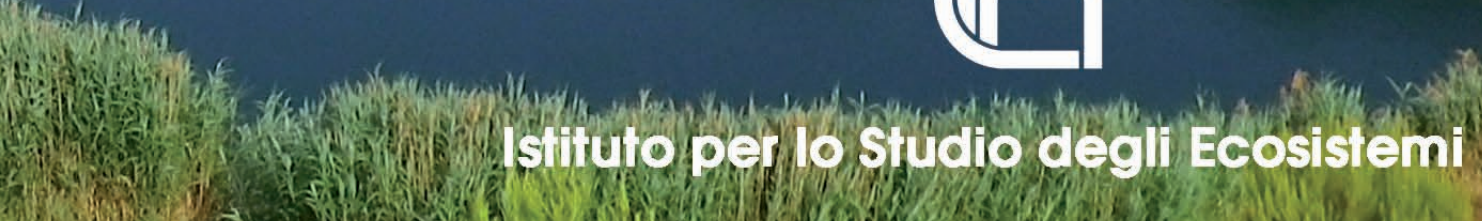




\section{Journal of Limnology \\ formerly Memorie dell Istituto Italiano di Idrobiologia}

The Journal of Limnology publishes peer-reviewed original papers, review papers and notes about all aspects of limnology. The scope of the Journal of Limnology comprises the ecology, biology, microbiology, physics, and chemistry of freshwaters, including the impact of human activities, management and conservation. Coverage includes molecular-, organism-, community-, and ecosystem-level studies both applied and theoretical. Proceedings of workshops, specialized symposia and conferences, may also be accepted for publication. The Journal of Limnology is published in three issues per year, open access online and each article is available for downloading for free. A printed version is also available at the annual subscription rate of $€ 120,00$. For further information on subscription terms, rates, methods of payment and shipping, etc., please contact the Publisher at info@pagepress.org

\section{Editor-in-Chief}

Roberto Bertoni, CNR-ISE Institute of Ecosystems Study, Verbania, Italy

\section{Associate Editors}

Esteban Balseiro, Laboratorio de Limnología, Universidad Nacional del Comahue, Bariloche, Argentina

Mariano Bresciani, CNR-IREA Milano, Italy

Cristiana Callieri, CNR-ISE Verbania, Italy

Laurence Carvalho, Scottish Freshwater Ecosystems Group, Centre for Ecology \& Hydrology, Midlothian, UK

Gianluca Corno, CNR-ISE Verbania, Italy

Stefano Fenoglio, DISAV, Università del Piemonte Orientale Amedeo Avogadro, Alessandria, Italy

Diego Fontaneto, CNR-ISE Verbania, Italy

Franz Hoelker, Leibniz Institute of Freshwater Ecology and Inland Fisheries, Berlin, Germany

Andrea Lami, CNR-ISE Verbania, Italy

Bernard Laval, Department of Civil Engineering, University of British Columbia, Vancouver, Canada

David M. Livingstone, EAWAG, Dübendorf, Switzerland

Marina Manca, CNR-ISE Verbania, Italy

Aldo Marchetto, CNR-ISE Verbania, Italy

Giuseppe Morabito, CNR-ISE Verbania, Italy

Michela Rogora, CNR-ISE Verbania, Italy

John P. Smol, Paleoecological Environmental Assessment and Research Lab., Queen's University, Kingston, Canada

Dietmar Straile, Limnological institute, University of Konstanz, Germany

Kay Van Damme, University of Ghent, Gent, Belgium

\section{Editorial Board}

Miguel Alonso, Departament d'Ecologia, Universitat de Barcelona, Spain

Jean Christophe Auguet, Centre National de la Recherche Scientifique, France

Marco Bartoli, Dipartimento di Scienze Ambientali, Università di Parma, Italy

Stefan Bertilsson, Department of Ecology \& Genetics, Limnology, Uppsala University, Sweden

Angela Boggero, CNR-ISE Verbania, Italy

Reinaldo L. Bozelli, Departamento de Ecologia, Instituto de Biologia, Universidade Federal do Rio de Janeiro, Brazil

George S. Bullerjahn, Department of Biological Sciences, Bowling Green State University, USA

Lluis Camarero, Centre de Recerca d'Alta Muntanya, Vielha, Spain

Marco Cantonati, MTSN Sezione Limnologia e Algologia, Trento, Italy

Manuela Coci, CNR-ISE Verbania, Italy

William R. DeMott, Indiana-Purdue University, Fort Wayne, USA

Claudia Dziallas, Department of Stratified Lake, Leibniz-Institute of Freshwater Ecology and Inland Fisheries, Stechlin, Germany

Walter Geller, Centre for Environmental Research - UFZ, Freiburg, Germany

Claudia Giardino, CNR-IREA Milano, Italy

Niels Jepsen, Section for Freshwater Fisheries Ecology, Technical University of Denmark, Silkeborg, Denmark

Ora Johannsson, Dept. of Fisheries and Oceans, Great Lakes Laboratory for Fisheries and Aquatic Sciences, Hamilton, Canada

Christian Kamenik, Geographisches Institut - Physische Geographie, Universität Bern, Switzerland

Suzanne N. Levine, Rubenstein School of Environment and Natural Resources, University of Vermont, Burlington, USA

Steven Loiselle, Dipartimento Farmaco Chimico Tecnologico, Università di Siena, Italy

Gian Marco Luna, CNR - Istituto di Scienze Marine, Venezia, Italy 
Hugh MacIsaac, Great Lakes Institute for Environmental Research, University of Windsor, Canada Paco Melià, Dipartimento di Elettronica e Informazione, Politecnico di Milano, Italy

Beatriz E. Modenutti, Laboratorio de Limnología, Universidad Nacional del Comahu, Bariloche, Argentina

Luigi Naselli-Flores, Dipartimento di Biologia Ambientale e Biodiversità, Università di Palermo, Italy

Liisa Nevalainen, Department of Geosciences and Geography, University of Helsinki, Finland

Roberta Piscia, CNR-ISE Verbania, Italy

Giampaolo Rossetti, Dipartimento di Scienze Ambientali, Università di Parma, Italy

Michaela Salcher, Limnological Station, Institute of Plant Biology, University of Zurich, Switzerland

Nico Salmaso, IASMA - Centro Ricerca e Innovazione, Fondazione Mach-Istituto Agrario di S. Michele all'Adige, Italy

Hugo Sarmento, Departament de Biologia Marina i Oceanografia, Institut de Ciències del Mar, Barcelona, Spain

Ruben Sommaruga, Institute of Ecology, University of Innsbruck, Austria

Mauro Tonolla, Istituto Cantonale Batteriosierologico, Bellinzona, Switzerland

Pierluigi Viaroli, Dipartimento di Scienze Ambientali, Università di Parma, Italy

Jaroslav Vrba, Dept. of Ecosystem Biology, Faculty of Science, University of South Bohemia, Ceske Budejovice, Czech Republic

Brian Whitton, School of Biological and Biomedical Sciences, University of Durham, UK

Ian J. Winfield, Centre for Ecology \& Hydrology, Lancaster Environment Centre, Lancaster, UK

\section{Editorial Assistant}

Igor Cerutti, CNR-ISE Verbania, Italy

\section{Managing Editor}

Nadia Moscato, Pavia, Italy

Editor-in-Chief

Roberto Bertoni, CNR-ISE Verbania, Italy

Autorizzazione Cancelleria del Tribunale di Verbania N. 58 del 7 Ottobre 1959

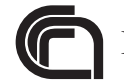

Istituto per lo Studio degli Ecosistemi, Verbania Pallanza, Italy

\section{Cover Photo}

Otranto lake, Italy (courtesy of R. Bertoni)

\section{Online Publication by}

PAGEPress Publications

via G. Belli 7

27100 Pavia, Italy

Tel. +39.0382 .1751762$

Fax +39.0382 .1750481$

\section{pagepress}

www.pagepress.org

ISSN: 1129-5767 eISSN 1723-8633 - www.jlimnol.it 


\section{INSTRUCTIONS TO AUTHORS}

\section{Manuscript language and ethical compliance}

Manuscripts must be submitted in English language and should conform to standard rules of British English grammar and style. Manuscripts submitted must not have been published or accepted for publication in any other journal and must not be under consideration for publication anywhere else. The manuscript publication must have been approved by all co-authors, if any, as well as by the responsible authorities - tacitly or explicitly - at the institute where the work has been carried out. The publisher will not be held legally responsible should there be any claims for compensation.

\section{Permissions}

Authors wishing to include figures, tables, or text passages that have already been published elsewhere are required to obtain permission from the copyright owner(s) for both the print and online format and to include evidence that such permission has been granted when submitting their papers. Any material received without such evidence will be assumed to originate from the authors.

The manuscript has to be prepared and structured as follows:

Manuscripts must be written in English language only. Authors whose native language is not English are strongly advised to have their manuscript checked by a language editing service, or by an English mother-tongue colleague prior to submission. The manuscript must be prepared with a standard word processor (preferably Microsoft Word or OpenOffice). Pages should be in A4 format and numbered. Times New Roman 12 pt is the advised font. Lines should be left numbered in continuum, to make the referees' work easier, and double-spaced.

Page 1: title of the contribution, full given name(s) and surname(s) of the author(s), mail address(es) and e-mail address for corresponding author, up to six key words, a condensed running head, number of tables and figures.

Page 2: abstract (between 350-400 words).

The body of the text beginning on page 3 should be organized as follows:

\section{INTRODUCTION \\ METHODS \\ RESULTS \\ Sub-heading 1 \\ Sub-heading 2 \\ DISCUSSION \\ CONCLUSIONS \\ ACKNOWLEDGMENTS \\ REFERENCES \\ Tables \\ Figures}

Figure legends

Particular attention should be taken to ensure that manuscripts exactly adhere to the journal style. In particular, take into account the following notes:

- Names of plants and animals and occasional expressions in Latin, Greek or languages other than English should be typed in italics.

- Authors must comply with the rules of biological nomencla- ture, as expressed in the International Code of Zoological Nomenclature, the International Code of Botanical Nomenclature, and the International Code of Nomenclature of Bacteria. When a species name is used for the first time in an article, it should be stated in full, and the name of its describer should also be given. Descriptions of new taxa should comprise official repository of types (holotype and paratypes), author's collections as repositories of types are unacceptable.

- Genus and species names should be in italics.

- Formulas should be centered, marked in the margin with an Arabic numeral in brackets, and separated from the text above and below by a blank line.

- References to figures and tables should be indicated, for example, as follows: (Fig. 1); (Figs. 1 and 2); (Tab. 1); (Tabs. 1 and 2).

- Symbols and combined expressions must be presented using negative exponents. Examples are given below:

\section{Tables}

Each table should be numbered with Arabic numerals. It should have a title or explanatory legend at the top. Data may not be presented in both tabular and graphical form. Tables must fit the page vertically with a printed width of either 80 or $170 \mathrm{~mm}$. Tables must be formatted as text, not as embedded images, and placed at the end of the manuscript.

\section{Figures}

The number of figures should be reasonable and justified: no more than $20 \%$ of the article. They must be numbered with Arabic numerals and placed at the end of the manuscript. Figures that are grouped together must be numbered using lowercase chronological letters. Figures should be a maximum final width of either 80,130 or $170 \mathrm{~mm}$. Lettering must be provided by the author(s). Letters, numbers and symbols must appear clearly, but not oversized. A suitable final size for lettering is $2 \mathrm{~mm}$ after reduction of the figure. It is recommended that one uniform lettering size be used throughout the manuscript. Graphs and histograms should be two-dimensional and scale marks provided. All lines (including boxes) should be clear, but not too thick and heavy. Black and white figures, including drawings and maps, must be originals executed in black on a clean white background. Photographs should be of excellent quality, with clear details and sufficient contrast. Coloured figures and graphs will be accepted; the printed version of the journal will have black-and-white figures, thus Authors must pay particular attention to the figures/graphs formatting and captions, in order to be understandable without solely referring to colours into the illustration itself (i.e. make graphs differentiation by colour and symbols).

Figures and graphs must be submitted as .tif or .jpg files, with the following digital resolution:

Color (saved as CMYK): minimum $300 \mathrm{dpi}$ Black and white/grays: minimum $600 \mathrm{dpi}$

MS Office files are also acceptable. Each figure should be clearly identified with figure number and author(s) name(s).

Cite literature in the text in chronological, followed by alphabetical order and formatted like these examples: Campbell (1983, 
1987b), (Smith et al., 1984; Karl and Craven, 1988; Korobi, 1997, 1998). In the References section, list citations in alphabetical, followed by chronological order.

Scientific names: give the Latin names of each species in full and in italics.

\section{Abbreviations \\ Abbreviations should be defined at first mention and used con- sistently thereafter.}

\section{Acknowledgments}

Acknowledgments of people, grants, funds, etc. should be placed in a separate section before the reference list. The names of funding organizations should be written in full.

\section{References}

All publications cited in the text should be listed, alphabetically after first author.

- For a single author, references are to be arranged chronologically. If an author published several papers in the same year, they should appear as: White JH, 1970a. ... - White JH, 1970b. ...

- If all authors are identical for two or more citations, chronological order of publication should dictate the order of citations.

- Papers which are in press should be cited only if formally accepted for publication. In this case the year should be that of the acceptance and indicated in brackets: White $\mathrm{H}$, Brown $\mathrm{J}$ (1990). (in press).

- Journal citations should be abbreviated based on 'World List of Scientific Periodicals' published by Butterworths, London. If the title of the journal is a single word do not abbreviate.

- Notations such as Vol., n., nr. are superfluous and should be dropped.

Some examples of correct citations are given below:

Callieri C, Stockner JG, 2002. Freshwater autotrophic picoplankton: a review. J. Limnol. 61:1-14.
Hutchinson GE, 1975. A treatise on limnology. 3. J. Wiley \& Sons, New York: $660 \mathrm{pp}$.

de Bernardi R, Giussani G, Lasso-Pedretti E, 1979. Food suitability and availability, demographic parameters and population growth in Daphnia obtusa Kurz under laboratory conditions. In: R. de Bernardi (Ed.), Proc. Symp. Biological and Mathematical aspects in population dynamics. Mem. Ist. ital. Idrobiol. Suppl. 37:233-242.

Muyzer G, Brinkhoff T, Wawer C, 1998. Denaturing gradient gel electrophoresis (DGGE) in microbial ecology, p. 1-27. In: A.D.L. Akkermans, J. D. van Elsas and F. J. Bruijn (eds.), Molecular microbial ecology manual. Kluwer Academic Publishers.

We recommend the use of a tool such as EndNote or Reference Manager for reference management and formatting.

EndNote reference styles can be searched for here: http://www.endnote.com/support/enstyles.asp Reference Manager reference styles can be searched for here: http://www.refman.com/support/rmstyles.asp

\section{Biodiversity data publication}

Authors are warmly encouraged to place all species distribution records in a publicly accessible database such as the national Global Biodiversity Information Facility (GBIF) nodes (www.gbif.org) or data centers endorsed by GBIF, including BioFresh (www.freshwaterbiodiversity.eu).

The Journal of Limnology is indexed by: Journal Citation Reports, Scopus, CrossRef, DOAJ, Aqualine Abstracts; Aquatic Sciences and Fisheries Abstracts (ASFA); Freshwater Biological Association (FBA); Geobase - Ecological Abstracts, Geographical Abstracts; Zoological Record; U.S. Fish and Wildlife Service - Wetland Values Database; NISC's FISHLIT database.

Impact factor 2012: 1.473 


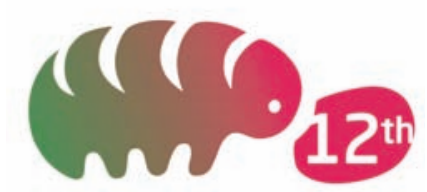

INTERNATIONAL SYMPOSIUM ON

TARDIGRADA

V. N. Gaia | Portugal

23-26 July 2012

\title{
$12^{\text {th }}$ International Symposium on TARDIGRADA
}

\author{
V.N. Gaia, Portugal \\ 23-26 July 2012
}

Proceedings Guest Editors

Lorena Rebecchi (University of Modena and Reggio Emilia, Italy)

Diane R. Nelson (East Tennessee State University, USA)

Roberto Bertolani (University of Modena and Reggio Emilia, Italy)

Paulo Fontoura (University of Porto, Portugal)

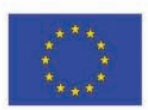

UNIÃO EUROPEIA

Fundo Europeu

de Desenvolvimento Regional

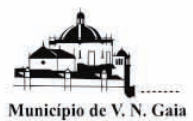

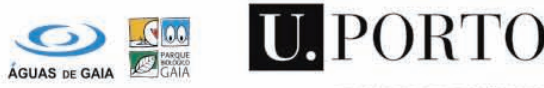

AGUAS E PARQUE BIOLOGICO DE

FC faculdade de cienncias 


\section{INTRODUCTION TO THE PROCEEDINGS}

The Twelfth International Symposium on Tardigrada has been a further, wonderful occasion to meet together and to exchange suggestions and opinions as a part of a common experience. Luckily, every symposium on tardigrades has always been followed by printed proceedings, and always of good quality. The symposium of Vila Nova de Gaia is not an exception. First of all, for your contributions. Twenty-three papers are included in these proceedings, published in the prestigious Journal of Limnology. Even though focused on tardigrades, they look diversified and very interesting. The topics of the proceedings include taxonomy and phylogeny at morphological (structure and ultrastructure) and molecular level, faunal studies, biogeography, stress tolerance, ecology (communities, life histories), methodologies and datasets. We must thank all the authors who honored the symposium by sharing the results of their research with talks and poster presentations. All of them represent the outcome of hard work and fascinating interests.

The scientific papers are preceded by the wishes of the organisers and the guest editors and more importantly by three tributes dedicated to dear colleagues, friends for some or most of us. In 2012, within just a few months, we lost Clark Beasley, Frank Romano and Jeanne Renaud-Mornant, a high number of colleagues with respect to our small community. The tributes here included are an occasion for many of us to remember interesting discussions and happy moments, and for some of us a scientific collaboration. Certainly these tributes do not fill the great void that these friends have left and that was already tangible during our meeting in Portugal, where we remembered Clark and we sent our greetings to Frank.

Regarding these proceedings, we must thank the availability of the Journal of Limnology, a milestone in tardigradology. This journal published the proceedings of the first symposium in 1975 under the old name of Memorie dell'Istituto Italiano di Idrobiologia dott. Marco de Marchi and before and later, with the same name, it published monographs on tardigrades by Ramazzotti $(1962,1972)$ and their supplements, the monograph by Ramazzotti and Maucci (1983), and several other papers by Ramazzotti. Under the name Journal of Limnology, in 2007 we had the proceedings of the $10^{\text {th }}$ International Symposium on Tardigrada, held in Catania (2006), for which we can again appreciate the quality of the journal. Now we are at the third experience, and we can only thank the editors of the journal, Gianluigi Giussani and Roberto Bertoni, both very willing and competent persons, with whom it is very easy to collaborate.

A special thank must be given to the many colleagues, tardigradologists and others, who have collaborated on the revision of the numerous contributions that enrich the proceedings of the $12^{\text {th }}$ International Symposium on Tardigrada. In most cases three reviewers have considered the contributions, an approach that never created problems but on the contrary has allowed improvement of the content due to an evaluation from different points of view. Lastly, we cannot forget Paul Bartels, Harry Meyer and Sandra McInnes who, together with each one of us, have been involved in the grammar (and not only) corrections of several papers. To them and to other colleagues who directly revised the text, we send our special and certainly not less important thanks. 


\section{$12^{\text {th }}$ INTERNATIONAL SYMPOSIUM ON TARDIGRADA}

Tardigrada Symposia take place every three years and are unique opportunities for tardigrade scientific researchers, students and other tardigrade enthusiasts from all over the world to get together and to promote scientific exchange and friendship.

Tardigradologists are not organised as a formal scientific society. Nevertheless, since the first Symposium, held in Pallanza, Italy, 1974, as a tribute to Giuseppe Ramazzotti, ten other conferences have been regularly organised. After the $11^{\text {th }}$ meeting held in 2009 at the University of Tübingen, Germany, we were honored with the responsibility to organise the next conference on behalf of the Faculty of Sciences of the University of Porto and the Parque Biológico de Gaia, Portugal. We would like to thank our fellow tardigradologists, especially the deans Diane Nelson, Roberto Bertolani, Hartmuth Greven and Reinhardt M. Kristensen, for their trust in our capability to organise the meeting.

The $12^{\text {th }}$ International Symposium on Tardigrada was held in Vila Nova de Gaia, Portugal, from 23-26 July, 2012. The meeting took place at the auditorium of the Parque Biológico de Gaia, a permanent centre of environmental education and nature conservancy.

There were a record number of attendees, more than 80 , coming from twenty countries from all over the world, presenting and discussing their latest findings on many diversified topics on tardigrade biology.

The scientific program was a success. The meeting included 36 oral and 40 poster presentations of high quality, about marine and limnic species, contributing to the integrative knowledge of the biology of these fascinating creatures. A special note should also be devoted to the high number of young researchers that attended the conference. Their presence is a guarantee for the future of tardigradology. Nineteen presentations were candidates for the Young Scientist Awards instituted to recognize and stimulate the scientific work developed by young researchers on Tardigrada. After a very difficult decision due to the excellent level of the presentations, the Jury constituted by senior scientists honored the oral presentation of Eliana Andrea Beltrán-Pardo about the DNA repair system of tardigrades and the poster of Vladimir Gross in which the muscular organization of marine and limnoterrestrial species had been analysed.

In addition to the promotion of scientific discussion and cooperation, symposia are events also providing contact with new cultures and moments of diversion. We have done our best to honor the traditional hospitality and authenticity of the Portuguese people, offering all the participants the opportunity to discover the charm, natural beauty and history of the cities of Gaia and Porto and to taste the wonderful Portuguese gastronomy. The Symposium included a visit to the port wine cellars, allowing the visitors to taste this worldwide famous nectar and get in touch with its history. A sightseeing tour at the seaside of Porto and Vila Nova de Gaia to admire the picturesque urban landscape and some stunning beaches, with a walk in the local nature reserve of the Douro estuary and park dunes of Aguda, ended by the conference dinner, was also included in the social program. Finally, an all-day boat cruise on the river Douro from Porto to Régua to admire the beautiful landscape combining lovely rural scenarios and vineyards shaped by human sweat was also held. The river Douro valley, rewarded in the $18^{\text {th }}$ century by the Marquis of Pombal with the title of the first demarcated wine region in the world, is considered a World Heritage Site by UNESCO since 2001. During the conference sessions, an additional social program for accompanying persons was also offered.

However, the success of the $12^{\text {th }}$ International Symposium on Tardigrada would not be possible without the support of some public and private organizations. We want to thank the Municipality of Vila Nova de Gaia, the University of Porto, the Comissão de Coordenação e Desenvolvimento Regional do Norte (CCDR-N, responsible for the execution of the Program ON.2 O Novo Norte co-funded by the European Regional Development Fund - ERDF), the Eco-Ethology Research Unit, the Grupo Taper and the Árvore Digital. We also received the help of many people to whom we are greatful. In particular, the Organizing Committee wants to thank the colleagues Diane Nelson, Roberto Bertolani and Lorena Rebecchi for their indispensable scientific collaboration. Without their help we would not have been able to accomplish this initiative. A special acknowledgment is devoted to all the members of the staff of Parque Biológico for their enthusiastic and patient work and also to some students of Biology (University of Porto) for their voluntary collaboration. Last but not least, we are also indebted to all the participants in the Symposium. Their amiable nature and range of expertise were responsible for four days of an agreeable atmosphere of friendship and science.

It was a great pleasure to host the $12^{\text {th }}$ International Symposium on Tardigrada in Vila Nova de Gaia. We sincerely wish an even greater success for the next symposium, where we hope to meet the old and new tardigradologists.

The Organising Committee

Paulo Fontoura (Faculdade de Ciências da Universidade do Porto)

Nuno Gomes Oliveira (Parque Biológico de Gaia)

Alexandre Valente (Faculdade de Ciências da Universidade do Porto)

Cristina Neves (Parque Biológico de Gaia) 

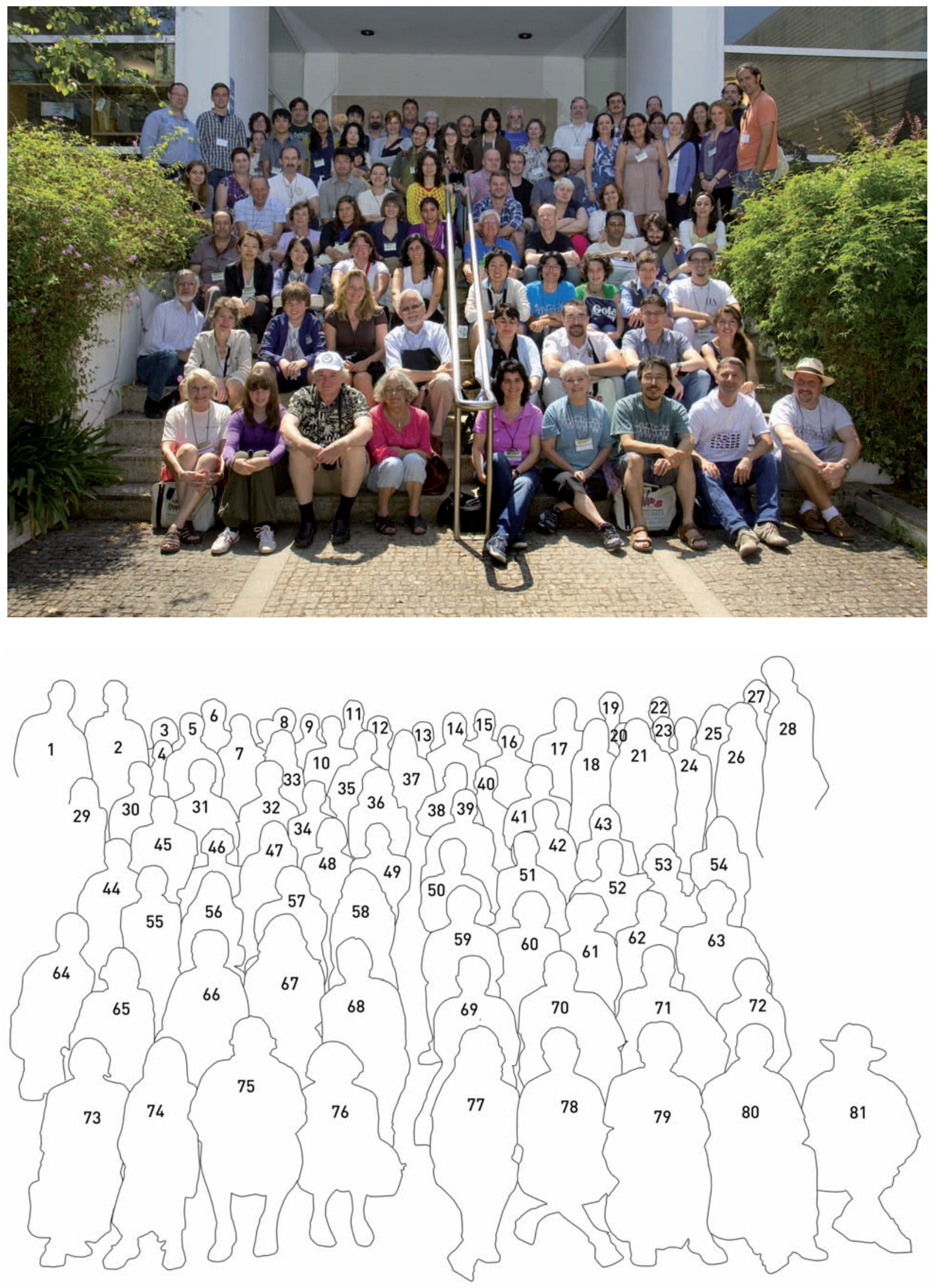


\section{$12^{\text {th }}$ INTERNATIONAL SYMPOSIUM ON TARDIGRADA}

July $23^{\text {rd }}-26^{\text {th }} 2012$, Vila Nova de Gaia (Portugal)

The participants

$1-$ F. Förster

$2-$ F. Bemm

$3-$ L. Grothman

$4-$ A. Grothman

$5-$ K. Oguchi

$6-$ G. Grothman

7 - B. Ramsay

$8-$ D. Horikawa

$9-$ R. Guidetti

10 - S. Gonçalves

$11-$ A. Jørgensen

12 - J. Eibye-Jacobsen

13 - M. Devetter

$14-\mathrm{K}$. Arakawa

$15-$ W.R. Miller

$16-$ J. Miller

$17-$ H.A. Meyer

$18-$ B. Luz

19 - Y. Kiosya

20 - M. Czerneková

$21-$ E. Santos

$22-\mathrm{V}$. Gross

23 - M. Bryndová

24 - C. Schulze

$25-$ M. Nottoli

$26-\mathrm{T}$. Tischer

27 - P. Bartels

28 - M. Rubal

29 - J. Cytan
30 - I. Poprawa
31 - P. Degma
32 - T. Kunieda
33 - S. Kawada-Suzuki with J. Suzuki
34 - B.V. Trygvadóttir
35 - J. Palhas
36 - A.I. Proença Pinto
37 - A. Cardoso
38 - D. Persson
39 - K.A. Halberg
40 - K. Zawierucha
41 - S. Quiroga
42 - C. Nilsson
43 - C. Rocha
44 - P. Fontoura
45 - R. Bertolani
46 - S. Ferrari
47 - V. Inshyna
48 - C. Gonçalves
49 - R. Londoño
50 - J. Nelson
51 - I. Jönsson
52 - T. Prasath
53 - D. Santos
54 - P. Veiga
55 - S. Tanaka
56 - S. Komine

$57-$ N. Guil

58 - A.M. Rocha

59 - T. Hashimoto

$60-$ S. Fujimoto

61 - B. Pappalardo

62 - S.J. McInnes

63 - Ł. Michalczyk

64 - N.G. Oliveira

65 - I. Šatkauskienè

66 - A.M. Jørgensen

$67-$ N. Møbjerg

$68-$ H. Greven

69 - L. Rebecchi

70 - O. Lisi

71 - G. Mayer

72 - E. Beltrán-Pardo

73 - J.G. Hinton

74 - S.M. Jørgensen

75 - R.M. Kristensen

76 - G.M. Kristensen

77 - T. Altiero

78 - D.R. Nelson

79 - A.C. Suzuki

80 - R.O. Schill

81 - N. Marley

Not in the photo:
A. Lyons
C. Neves 


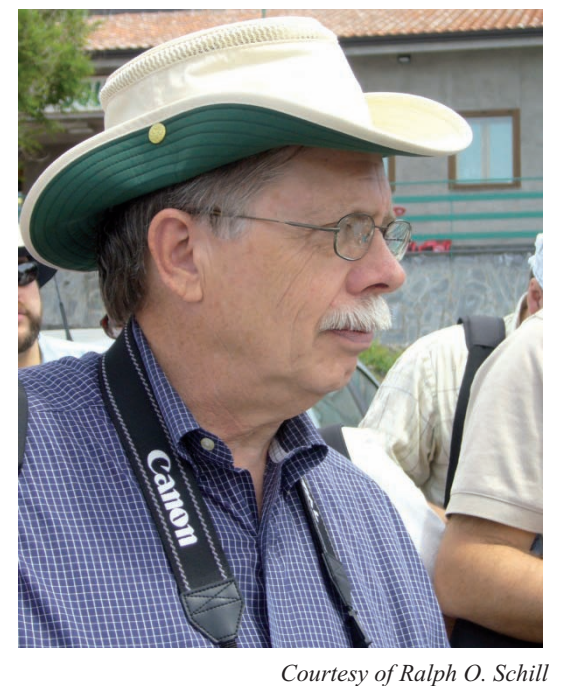

TRIBUTE TO DR. CLARK W. BEASLEY

Dr. Clark W. Beasley passed away unexpectedly in July 2012. We received the notice of his death shortly before the $12^{\text {th }}$ International Symposium on Tardigrada in Porto, Portugal, which he was planning to attend. A special tribute to Clark was presented at the beginning of the symposium by Dr. Paulo Fontoura.

After receiving his $\mathrm{PhD}$ in 1968 from the University of Oklahoma, Clark joined the Biology Department at McMurry College in College Station, Texas, USA, in 1969, becoming the chair in 1973. He was awarded the honour of Distinguished Professor in 1999. Even after his retirement from McMurry University in 2010, Clark continued his research on tardigrades and his interest in helping others with tardigrade taxonomy, especially those who were just beginning.

With his first publication on tardigrades from Kansas in 1967, Clark began a life-long interest in tardigrades. After his first symposium participation in the $3^{\text {rd }}$ International Symposium of Tardigrada at Johnson City, Tennessee, USA, in August 1980, he continued to be a regular at all the subsequent symposia, greeting all with his welcoming smile and hearty laughter. Assisted by others, Clark translated the Italian monograph Il Phylum Tardigrada (Ramazzotti and Maucci 1983) and published the English version, making it available worldwide. He also compiled a pdf bibliography of tardigrade publications through July 2010, which he shared with other tardigradologists. China held a special attraction for Clark, who made several field trips there, publishing articles on new records and new species from his extensive collections. Perhaps Clark's greatest contribution came in his role as the editor for 77 tardigrade publications in Zootaxa from 2001-2010.

Sandra McInnes summed it up well, Clark's support, assistance and guidance to both early stage researchers and those with longer track records will be sadly missed. My friendship with Clark goes back 32 years and is filled with sharing many fond memories of tardigrade symposia.

Diane R. Nelson 


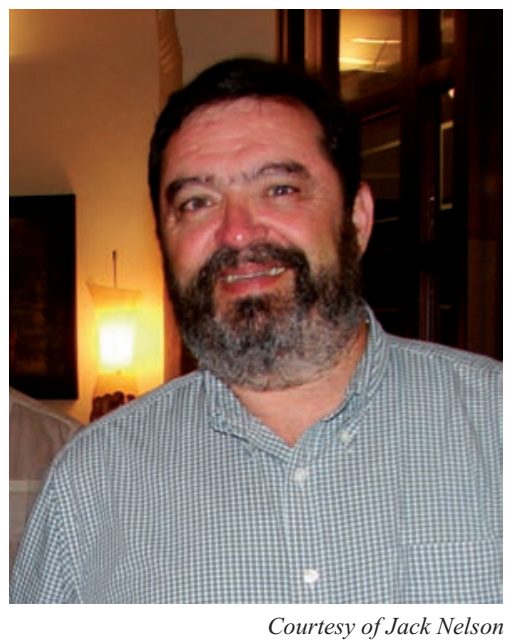

TRIBUTE TO DR. FRANK A. ROMANO III

Dr. Frank A. Romano III, retired chair of the Department of Biology, Jacksonville State University, Jacksonville, Alabama, USA, passed away on 17 August 2012 after an extended battle with esophageal cancer. Photos and videos of Frank and his students can be viewed on the JSU Biology web page, www.jsu.edu/biology

With a PhD from Syracuse University, Frank joined the JSU faculty in 1989 and became chair in 2002. He retired in May 2012, due to his illness. Throughout his career, his professionalism and rapport with his students and colleagues were unparalleled. He was selected for the 2010 Meritorious Teaching Award given by the Association of Southeastern Biologists. In honor of his retirement, the Dr. Frank Romano III Outdoor Classroom was dedicated at Jacksonville State University.

Frank had a unique ability to interest students in pursuing research, especially sharing his fascination and enthusiasm for working with tardigrades. Many of his students earned their Master's degrees at JSU studying the ecology of limno-terrestrial and marine tardigrades, and several presented their research at our international symposia. One of Frank's students, Dr. Brent Nichols, who went on to earn his $\mathrm{PhD}$ at the University of South Florida under Dr. Jim Garey, played a major role in organizing the $9^{\text {th }}$ International Symposium on Tardigrada in Tampa, Florida, USA, and served as one of the Guest Editors for the symposium volume published in Hydrobiologia.

Those of you who were fortunate to know Frank from his attendance at our international symposia were blessed to have a friend and a colleague who shared his enthusiasm for life and tardigrades and his positive outlook, sense of humor, and pride in his Italian heritage.

It has been 20 years since Frank asked me at an ASB meeting to help him and his students study tardigrades. I am privileged to have had such a long friendship with this dedicated man, who has meant so much to so many people.

Diane R. Nelson

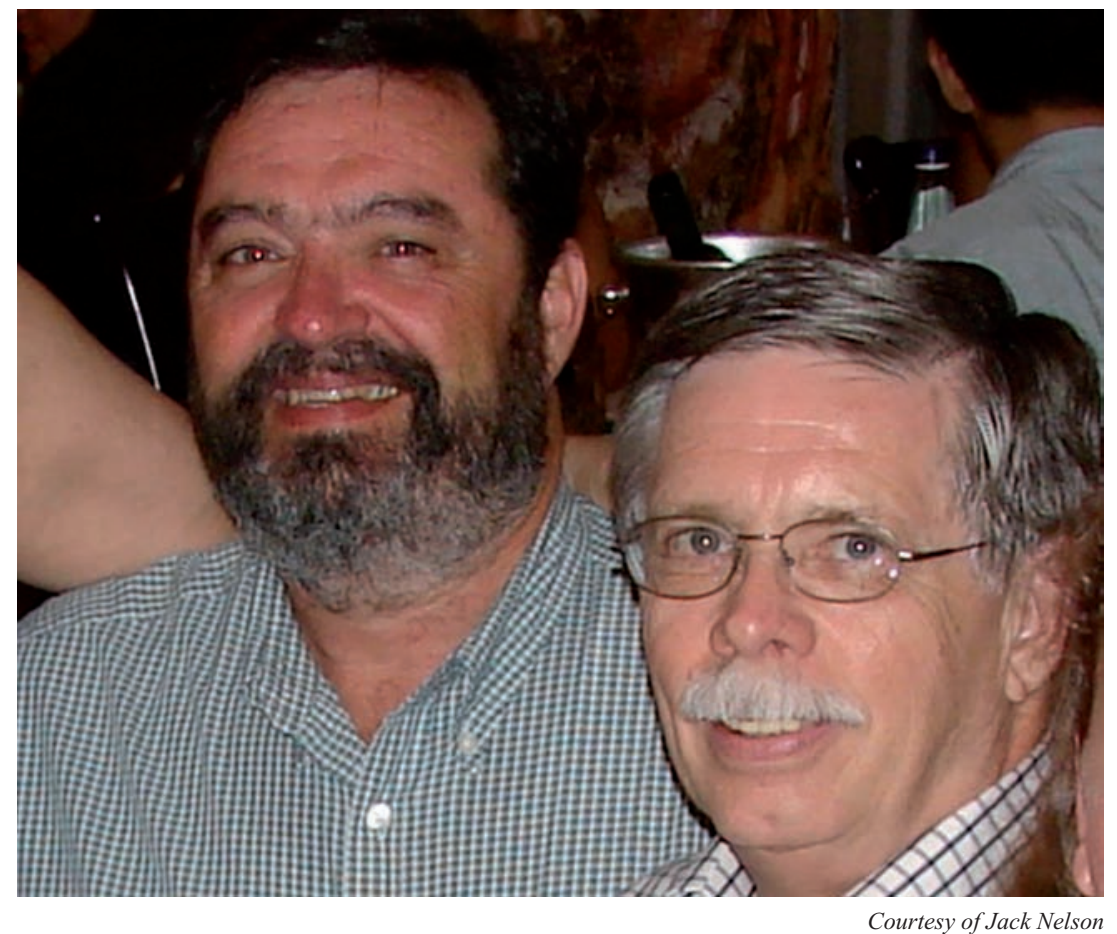




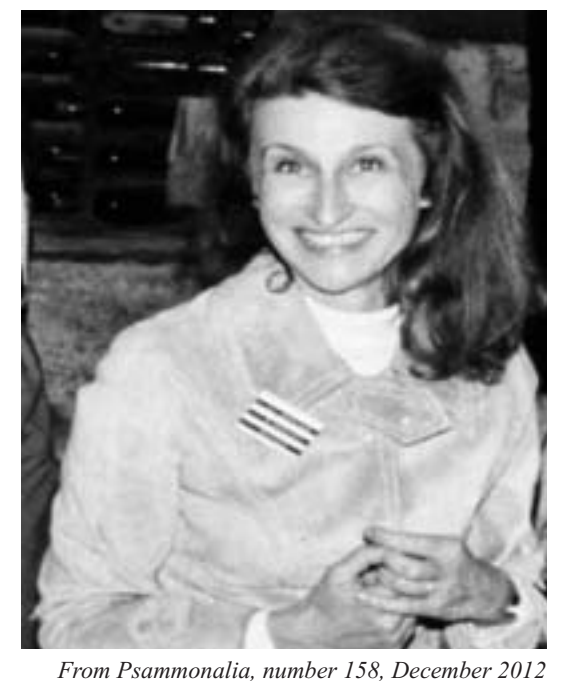

TRIBUTE TO DR. JEANNE RENAUD-MORNANT

Jeanne Renaud-Mornant passed away on 18 September 2012 in Paris. Retired since 1989, she was Directeur de Recherche Honoraire of the National Centre of Scientific Research (CNRS) in France.

Jeanne Renaud-Mornant was born in 1925 at Vellexon (Franche-Compté, Haute-Saône) near Besançon, France. After finishing the academic studies at the University of Bordeaux, she started her research activities at the Marine Station of Arcachon, France. The PhD thesis of Jeanne Renaud-Mornant, concluded in 1961, at Paris, under the supervision of Delamare-Debouteville, was an innovative document on the distribution of the interstitial micrometazoans in relation with the substrate. At that time, this document was considered a major event in meiofauna research.

During her long and remarkable career, Jeanne Re-
naud-Mornant specialized in taxonomy and ecology. She participated in diversified marine scientific expeditions all around the world, with special emphasis in the Atlantic ocean (French coast, Angola and Namibian coasts, Antilles and Brazil) and in the Pacific ocean (French Polynesia). She studied the fauna of very different ecosystems (e.g. estuaries, sandy beaches, coral reefs, abyssal deeps). Jeanne devoted her attention to several meiofaunal groups, such as Gastrotricha, Annelida, Crustacea, Loricifera, but definitely, her main interest was the study of tardigrades. She published important papers on morphology and phylogeny of tardigrades and described an impressive number of new taxa: 56 new tardigrade species (more than $25 \%$ of all the marine species known today), 17 new genera and 5 new families or subfamilies. She also participated in three of the four international tardigrade symposia from 1974 (first) to 1985 (fourth).

Her scientific and human qualities were widely recognized by her fellow researchers, allowing the development of numerous research projects in collaboration with a lot of international institutions (Universities, museums and marine stations), not only in Europe but also in North and South America. As a tribute to the work of Jeanne Renaud-Mornant, her name has been attributed to a large number of new taxa: several species of different phyla, and one genus and one family of tardigrades bear her name. The commitment of Jeanne to the formation of a new generation of marine biologists of diverse nationalities also deserves special mention.

We have lost a remarkable scientist, undoubtedly one of the more important names in tardigradology, and we are grateful for her incomparable contributions to the development of science.

The Guest Editors of the Proceedings of the $12^{\text {th }}$ International Symposium on Tardigrada 


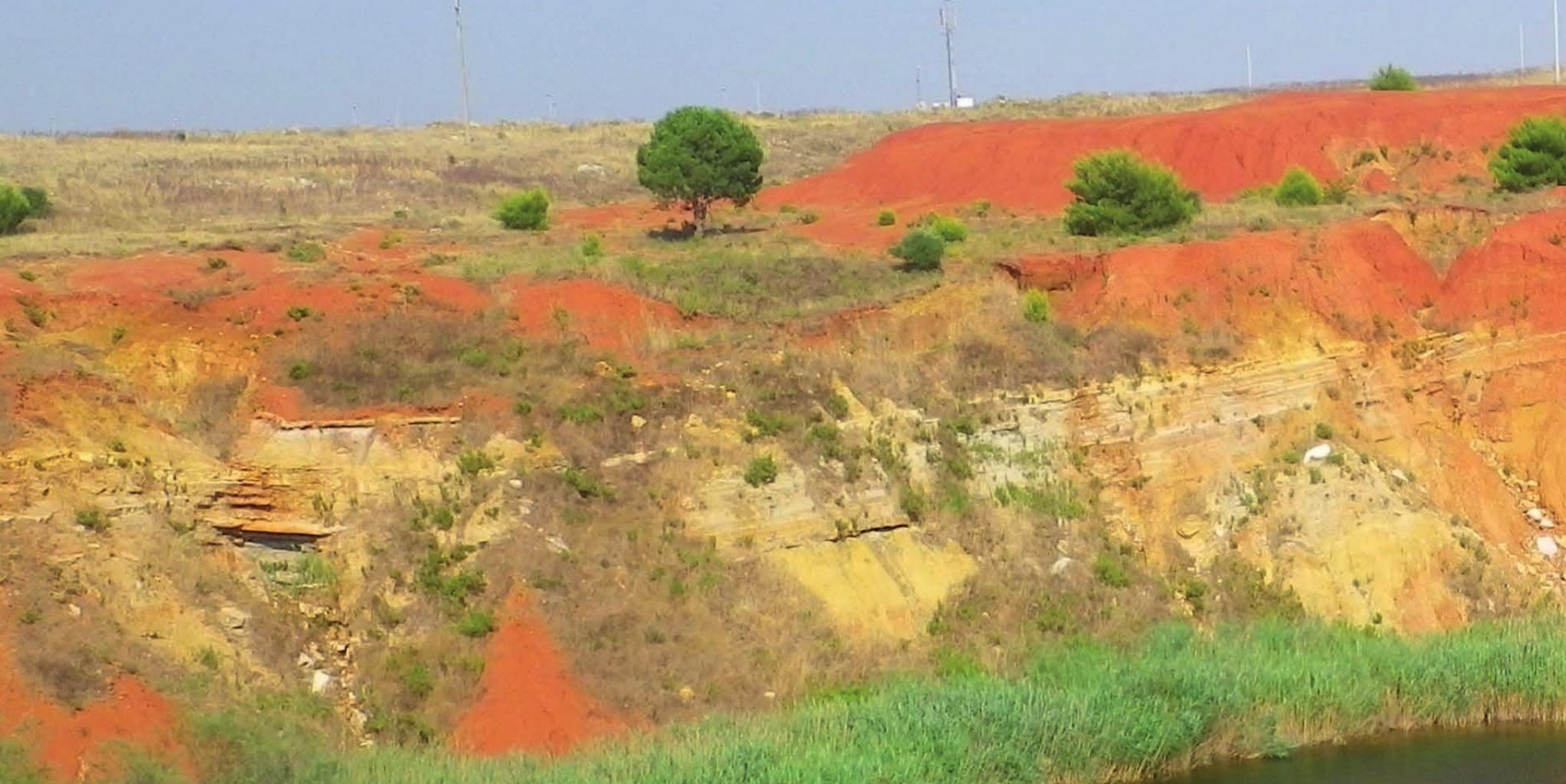

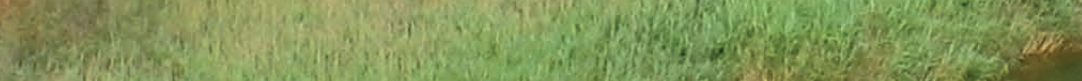

Whase

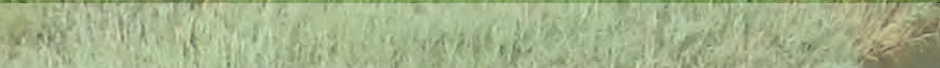

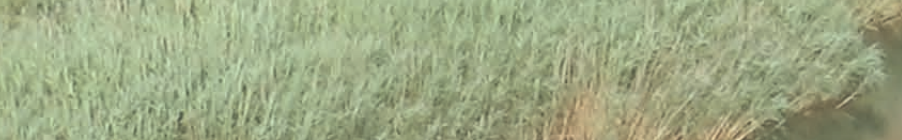

10.03

Q

(6) W.

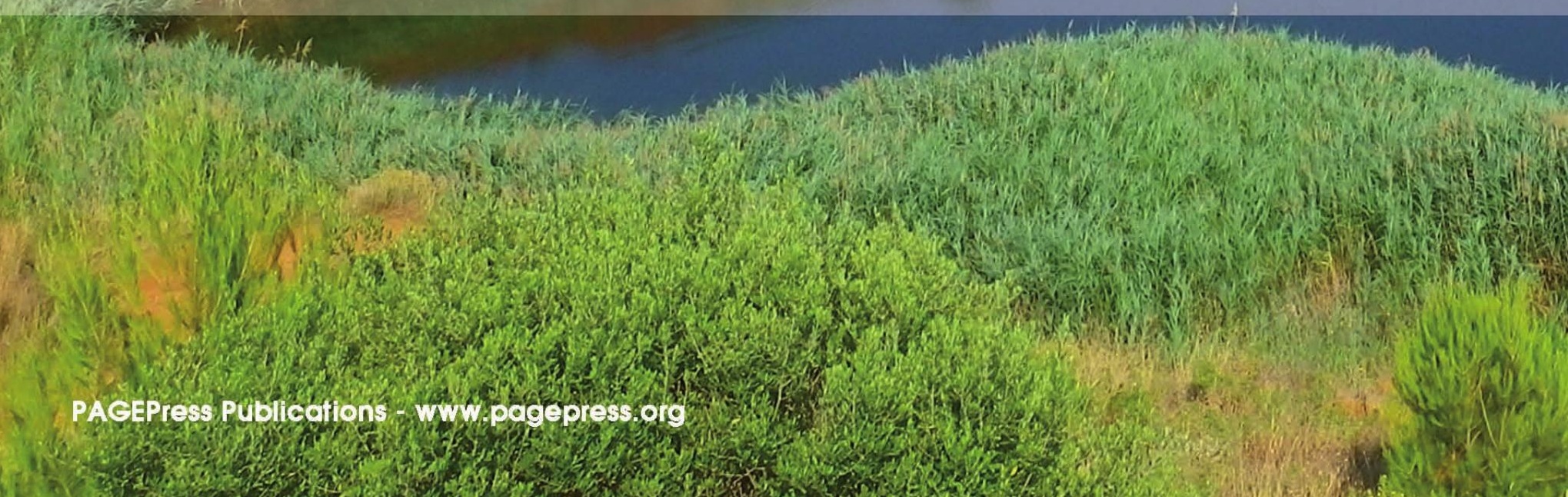

